Revista Eletrônica de Direito Processual - REDP.

Rio de Janeiro. Ano 16. Volume 23. Número 1. Janeiro a Abril de 2022

Periódico Quadrimestral da Pós-Graduação Stricto Sensu em Direito Processual da UERJ

Patrono: José Carlos Barbosa Moreira (in mem.). ISSN 1982-7636. pp. 1113-1141

www.redp.uerj.br

\title{
TERMO DE AJUSTAMENTO DE CONDUTA: ASPECTOS AINDA CONTROVERTIDOS ${ }^{1}$
}

\section{CONDUCT ADJUSTMENT TERM: ASPECTS STILL CONTROVERSED}

Paulo Henrique Amaral Motta

Doutorando em Direito pelo IDP - Instituto Brasileiro de Ensino, Desenvolvimento e Pesquisa. Mestre em Direito pela Universidade de Coimbra. Especialista em Direito Constitucional pela Fundação Escola Superior do Ministério Público. Professor em cursos de pós-graduação lato sensu. Promotor de Justiça em Cuiabá. Vinculado ao IDP - Instituto Brasileiro de Ensino, Desenvolvimento e Pesquisa. Cuiabá/MS. E-mail: paulo.motta@mpmt.mp.br.

RESUMO: O artigo em tela, fundado numa pesquisa bibliográfica, pretende analisar os aspectos ainda controvertidos atinentes ao termo de ajustamento de conduta. Primeiramente, após uma breve descrição de dados estatísticos relacionados com os tribunais brasileiros, que demonstram as dificuldades decorrentes da excessiva judicialização no país, são realizadas considerações acerca da utilidade do termo de ajuste para a solução consensual de conflitos coletivos. Outrossim, o presente texto busca, ainda, analisar as principais questões atuais relacionadas com o termo de ajustamento de conduta, inclusive através da apreciação de aspectos fundamentais para uma utilização adequada e eficiente do apontado ajuste.

PALAVRAS-CHAVE: Processo civil; solução consensual; termo de ajustamento de conduta; mediação; conciliação.

ABSTRACT: The present article, based on a bibliographical research, intends to analyze the still controversial aspects related to the conduct adjustment term. First, after a brief

\footnotetext{
${ }^{1}$ Artigo recebido em 17/08/2021 e aprovado em 15/12/2021.
} 
Revista Eletrônica de Direito Processual - REDP.

Rio de Janeiro. Ano 16. Volume 23. Número 1. Janeiro a Abril de 2022

Periódico Quadrimestral da Pós-Graduação Stricto Sensu em Direito Processual da UERJ

Patrono: José Carlos Barbosa Moreira (in mem.). ISSN 1982-7636. pp. 1113-1141

www.redp.uerj.br

description of statistical data related to Brazilian courts, which demonstrate the difficulties arising from excessive judicialization in the country, considerations are made about the usefulness of the adjustment term for the consensual solution of collective disputes. Furthermore, this text also seeks to analyze the main current issues related to the conduct adjustment term, including through the appreciation of fundamental aspects for an adequate and efficient use of the aforementioned adjustment.

KEYWORDS: Civil procedure; consensual solution; conduct adjustment term; mediation; conciliation.

\section{INTRODUÇÃO}

A partir do Relatório Justiça em Números $2020^{2}$, recentemente publicado pelo Conselho Nacional de Justiça, o qual objetiva divulgar, a cada ano, a realidade dos tribunais brasileiros, é possível verificar que o tempo médio de duração dos processos, nas fases de conhecimento e de cumprimento de sentença no $1^{\circ}$ grau acrescido do decurso temporal de tramitação no $2^{\circ}$ grau, alcança o excessivo lapso de 12 anos e 4 meses.

Se não bastasse isso, no sumário executivo do referido relatório ${ }^{3}$, ressai a informação de que o estoque processual da Justiça brasileira, em 2019, era, nada menos, de 77,1 milhões de processos em tramitação, sendo, tão somente, $12,5 \%$ solucionados pela via da conciliação.

Não há dúvida de que a crescente e exponencial litigiosidade observada não se sustenta, mostrando-se ineficaz e desarrazoada. Inclusive, na tutela coletiva, que versa, no mais das vezes, acerca da efetivação de direitos fundamentais de cunho social ou da implementação de políticas públicas, insistir na judicialização é atuar em prejuízo das promessas constitucionais construídas em benefício da sociedade brasileira ${ }^{4}$.

Por força disso, o termo de ajustamento de conduta permanece, apesar das questões controvertidas que o circundam, como um importante instrumento de solução

2 Disponível em: www.cnj.jus.br/wp-content/uploads/2020/08/WEB-V3-Justiça-em-Números-2020atualizado-em-25-08-2020.pdf. Acesso: 25/05/2021.

3 Disponível em: www.cnj.jus.br/wp-content/uploads/2020/08/WEB_V2-SUMARIO-EXECUTIVO_CNJJN2020.pdf. Acesso: 25/05/2020.

${ }^{4}$ Isso porque, com as dificuldades inerentes à judicialização das demandas coletivas, há um distanciamento da concretização dos direitos metaindividuais lançados no texto constitucional, dentre os quais, o direito ao meio ambiente equilibrado, o direito à moralidade administrativa, a proteção do consumidor. 
Revista Eletrônica de Direito Processual - REDP.

Rio de Janeiro. Ano 16. Volume 23. Número 1. Janeiro a Abril de 2022

Periódico Quadrimestral da Pós-Graduação Stricto Sensu em Direito Processual da UERJ

Patrono: José Carlos Barbosa Moreira (in mem.). ISSN 1982-7636. pp. 1113-1141

www.redp.uerj.br

consensual dos conflitos coletivos, apto a ensejar a pacificação social e a concretização dos direitos fundamentais.

Tendo como problema de pesquisa a análise dos aspectos ainda controvertidos atinentes ao termo de ajustamento de conduta, que impedem uma utilização adequada e eficiente do mesmo, o artigo pretende debater as questões doutrinárias essenciais relacionadas com o referido instrumento de solução de conflitos. Metodologicamente, trata-se de uma pesquisa teórica, do tipo descritiva, e para sua realização foi adotado o procedimento da revisão bibliográfica. Já a conclusão do artigo advém de uma análise dedutiva.

\section{O TERMO DE AJUSTAMENTO DE CONDUTA NA AUTOCOMPOSIÇÃO DE CONFLITOS COLETIVOS}

\subsection{Noções gerais}

Em tempos de crise de judicialização, quando a ação coletiva não vem alcançando a tutela pretendida, seja pela morosidade processual observada, seja pela ineficiência do provimento jurisdicional, ressai a conveniência de aprimorar a autocomposição na tutela coletiva, para cuja finalidade o termo de ajustamento de conduta mostra-se essencialmente útil.

Numa linha preliminar, há a necessidade de tecer alguns comentários gerais acerca do compromisso de ajustamento de conduta instituído pelo ordenamento jurídico pátrio. Nesse sentido, após a vigência da Lei de Ação Civil Pública, qual seja a Lei n. 7.347/85, houve, com a edição do Código de Defesa do Consumidor, que acrescentou os $\S \S 4^{\circ}, 5^{\circ} \mathrm{e}$ $6^{\circ}$ ao artigo $5^{\circ}$ daquela $1 e^{5}$, expressa disposição a assegurar aos órgãos públicos colegitimados, incluindo o Ministério Público, a possibilidade de celebrar acordos para solucionar ou prevenir conflitos coletivos, mediante cominações ${ }^{6}$.

\footnotetext{
${ }^{5}$ Merece destaque, no presente trabalho, o apontado $\S 5^{\circ}$, que assim dispôs: “Os órgãos públicos legitimados poderão tomar dos interessados compromisso de ajustamento de sua conduta às exigências legais, mediante cominações, que terá eficácia de título executivo extrajudicial."

${ }^{6}$ Apesar disso, o termo de ajustamento de conduta está previsto também em diversas outras disposições legais, dentre as quais, o Estatuto da Criança e do Adolescente (Lei n. 8.069/90, no seu artigo 112); a Lei Antitruste (Lei n. 23.529/2012, no seu artigo 85); e a Lei de Mediação (Lei n. 13.§40/2015).
} 
Revista Eletrônica de Direito Processual - REDP.

Rio de Janeiro. Ano 16. Volume 23. Número 1. Janeiro a Abril de 2022

Periódico Quadrimestral da Pós-Graduação Stricto Sensu em Direito Processual da UERJ

Patrono: José Carlos Barbosa Moreira (in mem.). ISSN 1982-7636. pp. 1113-1141

www.redp.uerj.br

Em consequência, o termo de ajustamento de conduta veio a constituir um título executivo extrajudicial, que prescinde de homologação pelo Poder Judiciário, a assegurar uma implementação das obrigações pactuadas na eventualidade de inadimplemento, tudo em busca da efetivação do interesse público tutelado ${ }^{7}$.

Para Paulo Valério Dal Pai Moraes ${ }^{8}$, o compromisso de ajustamento foi lançado no sistema jurídico brasileiro com a função inequívoca de solucionar, com rapidez e eficiência, os conflitos coletivos surgidos no convívio social, propiciando, assim, segundo Nelson Nery Júnior ${ }^{9}$, uma melhor agilidade e efetividade nos negócios jurídicos relacionados com os direitos difusos, coletivos e individuais homogêneos.

Por se tratar de um instrumento de autocomposição de conflitos, o termo de ajustamento dispensa a necessidade de uma ação coletiva, isentando os seus subscritores, ainda, de qualquer despesa processual ou de eventuais honorários de sucumbência, com a possibilidade, também, de uma solução concertada entre os interessados, onde podem ser fixados prazos, condições, multas e outras questões a partir do comum acordo.

Quanto a sua definição, José dos Santos Carvalho Filho ${ }^{10}$ o compreende como o "ato jurídico pelo qual a pessoa, reconhecendo implicitamente que sua conduta ofende interesse difuso ou coletivo, assume o compromisso de eliminar a ofensa através da adequação de seu comportamento".

Sem se ocupar, neste momento, com a natureza jurídica do ajustamento de conduta $^{11}$, evidente que o referido instituto possui, como principal objetivo, a celebração de um compromisso, que vise a adequação do comportamento daquele que atua lesando ou ameaçando de lesão direitos ou interesses difusos, coletivos ou individuais homogêneos ${ }^{12}$.

Tendo como marca essencial a consensualidade, o compromisso de ajustamento em análise possui a eficiência e a observância dos princípios garantistas do processo como

\footnotetext{
${ }^{7}$ Nesse sentido, vide NERY, Ana Luiza. Teoria geral do termo de ajustamento de conduta. São Paulo: Revista dos Tribunais, 2017, e-book.

${ }^{8}$ MORAES, Paulo Valério Dal Pai. O compromisso de ajustamento. Revista de Processo, São Paulo, vol. 30, abr./jun. 1999, p. 30-31.

${ }^{9}$ NERY JR., Nelson. Código de defesa do consumidor comentado pelos autores no anteprojeto. 5. ed. Rio de Janeiro: Forense Universitária, 1998, p. 800.

${ }^{10}$ CARVALHO FO., José dos Santos. Ação civil pública: comentários por artigo: Lei $n^{o} 7.347$, de 24/7/85.

8. ed. Rio de Janeiro: Lumen Juris, 2011, p. 137.

11 A natureza jurídica do termo de ajustamento de conduta, objeto de amplos debates doutrinários, será apreciada no próximo tópico.

${ }^{12}$ Em consequência, acaba por haver, também, a solução consensual do conflito coletivo de interesses.
} 
Revista Eletrônica de Direito Processual - REDP.

Rio de Janeiro. Ano 16. Volume 23. Número 1. Janeiro a Abril de 2022

Periódico Quadrimestral da Pós-Graduação Stricto Sensu em Direito Processual da UERJ

Patrono: José Carlos Barbosa Moreira (in mem.). ISSN 1982-7636. pp. 1113-1141

www.redp.uerj.br

características essenciais, tudo a assegurar uma proteção aos direitos transindividuais ${ }^{13}$.

Com tais atributos, o termo de ajustamento de conduta possui, portanto, destacada utilidade para a solução dos conflitos coletivos, servindo a uma essencial pacificação social, com um forte caráter democrático ${ }^{14}$, o que deve permear todo o processo brasileiro.

\subsection{A controvérsia acerca da natureza jurídica do termo de ajustamento de conduta}

Para que o termo de ajustamento possa ser utilizado, dentro de todo o seu potencial solucionador de conflitos coletivos, há a necessidade de debater e compreender as questões ainda controversas que alcançam a sua natureza jurídica.

Nesse ponto, qual seja a natureza jurídica do compromisso de conduta, a doutrina a analisa sob diferentes enfoques, sendo os principais quanto a sua eficácia, a sua forma e o seu conteúdo. Acerca desse tema, há intensa discussão doutrinária, que vem ensejando o desenvolvimento de uma sólida pesquisa acadêmica dentre autores brasileiros.

Quanto a sua eficácia, conforme acima apontado e em decorrência de uma interpretação literal da Lei n. 7.347/85, o termo de ajustamento de conduta constitui um título executivo extrajudicial, o que afasta a necessidade do processo de conhecimento, usualmente moroso e complexo.

No que se refere à sua forma, há variadas concepções na doutrina, das quais, as principais serão a seguir apontadas.

Para Hugo Nigro Mazzilli ${ }^{15}$, o compromisso de ajustamento de conduta constitui um ato administrativo negocial e unilateral, onde, apenas e tão somente, aquele que lesa ou ameaça de lesão o direito/interesse pode se comprometer.

No entanto, esse entendimento apresenta equívocos, pois, ao entabular o referido compromisso, o órgão público subscritor também acaba por se comprometer, até mesmo

\footnotetext{
${ }^{13}$ Nesse sentido, vide PINHO, Humberto Dalla Bernardina de; FARIAS, Bianca Oliveira de. Apontamentos sobre o compromisso de ajustamento de conduta na Lei de Improbidade Administrativa e no Projeto de Lei da Ação Civil Pública. Revista Eletrônica de Direito Processual, Rio de Janeiro, vol. IV, p. 25-53, 2009.

${ }^{14}$ Sustentando que a solução consensual de conflitos possui um forte caráter democrático, vide DIDIER JR., Fredie. Curso de direito processual civil: introdução ao direito processual civil, parte geral e processo de conhecimento. 21 ed. Salvador: Editora Juspodvm, 2019, p. 323.

${ }^{15}$ MAZZILLI, Hugo Nigro. Compromisso de ajustamento de conduta: análise à luz do anteprojeto do código brasileiro de processos coletivos. In: GRINOVER, Ada Pellegrini; MENDES, Aluisio Castro; WATANABE, Kazuo (coords.). Direito processual coletivo e o anteprojeto de código brasileiro de processos coletivos. São Paulo: Revista dos Tribunais, 2007, p. 238.
} 
Revista Eletrônica de Direito Processual - REDP.

Rio de Janeiro. Ano 16. Volume 23. Número 1. Janeiro a Abril de 2022

Periódico Quadrimestral da Pós-Graduação Stricto Sensu em Direito Processual da UERJ

Patrono: José Carlos Barbosa Moreira (in mem.). ISSN 1982-7636. pp. 1113-1141

www.redp.uerj.br

porque, uma vez adimplidas todas as obrigações assumidas consensualmente, não poderá a administração pública ajuizar aquela específica demanda versada no título extrajudicial, nem mesmo executá-lo.

Além disso, o compromisso de ajustamento distancia-se muito de um ato administrativo, o qual, segundo conceito clássico de Hely Lopes Meirelles ${ }^{16}$, é toda manifestação de vontade da administração pública, que tenha por finalidade imediata adquirir, resguardar, transferir, modificar, extinguir ou declarar direitos, bem como impor obrigações, não se confundindo, por certo, com o instituto negocial em estudo.

Numa segunda corrente doutrinária, Rodrigo Fernandes ${ }^{17}$ afirma tratar-se de um contrato administrativo, visto que o compromisso decorreria de um acordo, onde a administração pública, assim representada por um dos colegitimados, busca a reparação ou a manutenção do direito coletivo lesado ou ameaçado de lesão.

No entanto, para tal autor, que aponta o compromisso como uma espécie de contrato, mas administrativo, embora o termo de ajustamento venha a encerrar obrigações apenas para uma das partes, qual seja o interessado, também dependeria da concordância de todos os demais signatários para ser celebrado.

Ainda assim, caracterizar o termo de ajustamento de conduta como um contrato administrativo, seria dispensar todas as peculiaridades decorrentes da Lei de Licitações, bem como do regime jurídico específico que o alcança, sendo impossível confundir institutos jurídicos tão distintos e distantes.

Por fim, numa terceira posição doutrinária, Ana Luiza Nery ${ }^{18}$, bem como Fredie Didier Jr. e Hermes Zaneti Jr. ${ }^{19}$ sustentam que o termo de ajustamento de conduta seria um negócio jurídico bilateral, em que se reconhece a finalidade de adquirir, modificar ou extinguir direitos, com o objetivo final de reparar ou evitar a lesão a um bem de natureza coletiva lato sensu.

Justamente por criar uma relação jurídica material ou processual ${ }^{20}$, que verse acerca

\footnotetext{
${ }^{16}$ MEIRELLES, Hely Lopes. Direito administrativo brasileiro. 42. ed. São Paulo: Malheiros, 2016, p. 150.

${ }^{17}$ FERNANDES, Rodrigo. Compromisso de ajustamento de conduta ambiental. Rio de Janeiro: Renovar, 2008, p. 78.

18 NERY, Ana Luiza. Teoria geral do termo de ajustamento de conduta. São Paulo: Revista dos Tribunais, 2017, e-book.

${ }^{19}$ DIDIER JR, Fredie; ZANETI JR., Hermes. Curso de direito processual civil: processo coletivo. 9. ed. Salvador: Editora Juspodvm, 2014, p. 293-294.

${ }^{20}$ Processual, pois o ordenamento jurídico pátrio, conforme será demonstrado adiante, não impede que haja a
} 
Revista Eletrônica de Direito Processual - REDP.

Rio de Janeiro. Ano 16. Volume 23. Número 1. Janeiro a Abril de 2022

Periódico Quadrimestral da Pós-Graduação Stricto Sensu em Direito Processual da UERJ

Patrono: José Carlos Barbosa Moreira (in mem.). ISSN 1982-7636. pp. 1113-1141

www.redp.uerj.br

de direitos ou interesses difusos, coletivos ou individuais homogêneos, constituindo, modificando ou constituindo negativamente direitos, pretensões, exceções ou encargos, no âmbito de uma consensualidade negociada, inexistem dúvidas de que o termo de ajustamento, quanto a sua forma, constitui um negócio jurídico bilateral, ainda que persistam tantas outras posições doutrinárias divergentes.

Quanto ao seu conteúdo, os debates doutrinários são ainda mais intensos, havendo posicionamentos díspares que acabam por considerar o compromisso de ajustamento uma transação, um mero acordo, ou, ainda, um reconhecimento jurídico do pedido, o que possui estreita relação com o nível de disponibilidade existente na sua celebração.

Segundo Paulo Cezar Pinheiro Carneiro ${ }^{21}$, o compromisso possui a natureza de reconhecimento jurídico do pedido, o qual se dá pelo interessado, que lesa ou ameaça de lesão o direito/interesse coletivo. Com esse entendimento, não há, no bojo do compromisso de ajustamento, qualquer possibilidade de transação, ou, até mesmo, de negociar consensualmente os termos de um acordo relacionado ao conflito coletivo, havendo, assim, uma rígida adesão do interessado à proposta do órgão colegitimado, o que, por certo, enfraquece a sua utilização na autocomposição.

Outra linha doutrinária compreende o termo de ajustamento como um mero acordo, qual seja um acordo em sentido estrito, no qual o interessado apenas cede aos termos propostos pelo órgão colegitimado, sem qualquer concessão recíproca. Nesse sentido, Paulo Leme Machado ${ }^{22}$ sustenta, por entender não ser possível qualquer disposição de direitos indisponíveis, que se mostra apropriado classificar o compromisso de ajustamento como um acordo.

Acompanhando esse entendimento, com o argumento de que não haveria concessões recíprocas no ajustamento de conduta, mas, na verdade, um mero acordo acerca dos direitos coletivos lato sensu envolvidos, com a mera disposição das condições de cumprimento das obrigações, merece destaque a abalizada doutrina de Alexandre Amaral

celebração de termo de ajustamento de conduta versando acerca de questões meramente processuais, num verdadeiro negócio jurídico processual, seja precedente ou incidental a uma ação coletiva lato sensu.

${ }^{21}$ CARNEIRO, Paulo Cezar Pinheiro. Acesso à Justiça: juizados especiais cíveis e ação civil pública: uma nova sistematização da teoria geral do processo. Rio de Janeiro: Forense, 2007, p. 236.

22 MACHADO, Paulo Affonso Leme. Direito ambiental brasileiro. 24 ed. São Paulo: Malheiros, 2016, p. 379-380. 
Revista Eletrônica de Direito Processual - REDP.

Rio de Janeiro. Ano 16. Volume 23. Número 1. Janeiro a Abril de 2022

Periódico Quadrimestral da Pós-Graduação Stricto Sensu em Direito Processual da UERJ

Patrono: José Carlos Barbosa Moreira (in mem.). ISSN 1982-7636. pp. 1113-1141

www.redp.uerj.br

Gavronski ${ }^{23}$.

Além desses autores, também para Fernando Reverendo Vidal Akaoui ${ }^{24}$, Sérgio Shimura $^{25}$ e Wallace Paiva Martins Junior ${ }^{26}$, o termo de ajustamento de conduta constitui tão somente um acordo. Para a doutrina acima apontada, que se apresenta minoritária, a utilização da nomenclatura "transação" seria inadequada, visto que, no ajuste de conduta, não há qualquer margem de disponibilidade sobre o objeto, e, ainda que verse acerca de direito disponível, o órgão colegitimado para a sua celebração não deteria qualquer poder para não pleitear algo em favor dos titulares do direito lesado ou ameaçado de lesão ${ }^{27}$.

Por último, há aqueles autores que defendem ser o compromisso de ajustamento uma transação ${ }^{28}$, cuja justificativa principal seria a presença de concessões mútuas, ainda que limitadas em relação ao legitimado, para prevenir ou solucionar o conflito $^{29}$, o que aparenta ser o melhor entendimento.

Embora Rodolfo de Camargo Mancuso ${ }^{30}$ admita a transação em matéria coletiva, mas a restrinja apenas à fase judicial, e não, portanto, como instrumento de solução extrajudicial de conflitos coletivos, outros autores, como Daniel Roberto Fink ${ }^{31}$ e Ana Luiza Nery ${ }^{32}$ entendem que o referido título executivo extrajudicial possui a natureza jurídica de transação.

${ }^{23}$ GAVRONSKI, Alexandre Amaral. Técnicas extraprocessuais de tutela coletiva. São Paulo: Editora Revista dos Tribunais, 2010, p. 382. No mesmo sentido, Geisa de Assis Rodrigues, na sua tese de doutorado, com o título "Termo de Ajustamento de Conduta: a construção de uma solução extrajudicial de conflitos transindividuais democráticos", defendida em 2000, pela Universidade do Estado do Rio de Janeiro.

${ }^{24}$ AKAOUI, Fernando Reverendo Vidal. Compromisso de ajustamento de conduta ambiental. São Paulo: Editora Revista dos Tribunais, 2015, e-book.

${ }^{25}$ SHIMURA, Sergio. Título executivo. São Paulo: Saraiva, 1997, p. 379.

${ }^{26}$ MARTINS JR., Wallace Paiva. Administração pública, resolução extrajudicial de conflitos e compromisso de ajustamento de conduta. Revista de Direito Administrativo e Infraestrutura, São Paulo, vol. 8, jan./mar. 2019 , p. 99.

27 AKAOUI, Fernando Reverendo Vidal. Compromisso de ajustamento de conduta ambiental. São Paulo: Editora Revista dos Tribunais, 2015, e-book.

${ }^{28} \mathrm{Na}$ jurisprudência do Superior Tribunal de Justiça, no REsp n. 299.400/RJ, houve expressa manifestação quanto a ser o ajustamento de conduta uma transação.

${ }_{29}$ ALVIM, Thereza; CUNHA, Ígor Martins da. Termo de ajustamento de conduta, mediação e conciliação: uma breve reflexão a respeito do negócio jurídico que previne ou resolve conflito que envolve direitos difusos, coletivos e individuais homogêneos. Revista de Processo, São Paulo, vol. 304, jun. 2020, p. 383.

${ }^{30}$ MANCUSO, Rodolfo de Camargo. Ação civil pública: em defesa do meio ambiente, do patrimônio cultural e dos consumidores: Lei $n^{\circ} 7.347 / 85$ e legislação complementar. 15. ed. São Paulo: Revista dos Tribunais, 2019, e-book.

${ }^{31}$ FINK, Daniel Roberto. Alternativa à ação civil pública ambiental (reflexões sobre as vantagens do termo de ajustamento de conduta). In: MILARÉ, Édis. Ação civil pública: Lei 7.347/85: 15 anos. São Paulo: Revista dos Tribunais, 2001, p. 119-120.

${ }^{32}$ NERY, Ana Luiza. Teoria geral do termo de ajustamento de conduta. São Paulo: Revista dos Tribunais, 2017, e-book. 
Revista Eletrônica de Direito Processual - REDP.

Rio de Janeiro. Ano 16. Volume 23. Número 1. Janeiro a Abril de 2022

Periódico Quadrimestral da Pós-Graduação Stricto Sensu em Direito Processual da UERJ

Patrono: José Carlos Barbosa Moreira (in mem.). ISSN 1982-7636. pp. 1113-1141

www.redp.uerj.br

E transação, justamente porque o compromisso de ajustamento se caracteriza por concessões recíprocas entre os seus signatários, quais sejam o órgão público tomador do ajuste e o interessado, a configurar, portanto, a existência de direitos e obrigações mútuas.

Tal entendimento torna o ajustamento de conduta útil para a solução consensual de conflitos coletivos, atendendo, assim, aos direitos e interesses de ambas as partes, tanto do órgão público colegitimado, quanto do interessado.

Pensar de maneira distinta, ao defender que a natureza jurídica do compromisso de conduta é a de um mero acordo, o tornaria ineficiente e, até mesmo, inviável ao seu subscritor. Nesse sentido, ao limitar o TAC a uma mera subsunção ao pretendido pelo órgão público, bastaria ao interessado submeter-se à ação judicial e aguardar o pronunciamento do Poder Judiciário, que, inclusive, poderia vir a ser favorável, ainda que parcialmente, ao seu interesse.

Entretanto, Patricia Pizzol ${ }^{33}$, ao reconhecer que o ajustamento possui natureza de transação, posto que qualificado por concessões mútuas entre os seus signatários, adverte que não cabe ao órgão público colegitimado a renúncia aos direitos transindividuais, motivo pelo qual o compromisso de conduta seria uma transação peculiar.

E tal renúncia está relacionada com o conceito de indisponibilidade material dos direitos versados no termo de ajustamento de conduta, o que será tratado no próximo tópico ante a sua importância.

Destarte, afastando as noções de que o TAC seria um mero acordo, ou, ainda, um reconhecimento jurídico do pedido pelo interessado, mas, na verdade, uma transação, ainda que marcada por peculiaridades ausentes no regime jurídico previsto no Código Civil, em seus artigos 840 a 850 , é possível concluir que, ao celebrá-lo, seus subscritores buscam a melhor alternativa possível ao conflito, visando reparar ou evitar a lesão a um bem de natureza transindividual.

Portanto, o termo de ajustamento de conduta pode ser compreendido como um título executivo extrajudicial, que constitui um negócio jurídico bilateral, posto que marcado por um ajuste inter partes, proveniente de uma transação, assim marcada por uma consensualidade negociada.

\footnotetext{
${ }^{33}$ PIZZOL, Patricia. Liquidação nas ações coletivas. São Paulo: Lejus, 1998, p. 149-153.
} 
Revista Eletrônica de Direito Processual - REDP.

Rio de Janeiro. Ano 16. Volume 23. Número 1. Janeiro a Abril de 2022

Periódico Quadrimestral da Pós-Graduação Stricto Sensu em Direito Processual da UERJ

Patrono: José Carlos Barbosa Moreira (in mem.). ISSN 1982-7636. pp. 1113-1141

www.redp.uerj.br

\subsection{A indisponibilidade dos direitos coletivos lato sensu e o termo de ajustamento de conduta}

Uma vez compreendido que o termo de ajustamento consiste num negócio jurídico bilateral proveniente de uma transação, outra questão controvertida assume relevo, qual seja a superação do dogma da indisponibilidade absoluta dos direitos coletivos lato sensu ${ }^{34}$.

Conforme defendem Humberto Dalla Bernardina de Pinho e Ludmilla Camacho Duarte $\operatorname{Vidal}^{35}$, a partir de uma ponderação entre os riscos advindos de uma judicialização marcada por todas as dificuldades processuais que precedem uma análise do direito material coletivo buscado com as vantagens obtidas a partir de um termo de ajustamento de conduta, e admitida a natureza jurídica de transação ao referido ajuste, impõe-se o reconhecimento da viabilidade da negociação, desde que não haja renúncia ao direito coletivo lato sensu no seu núcleo essencial ${ }^{36}$.

Portanto, na negociação do compromisso de ajustamento, a assegurar uma efetiva tutela dos direitos e interesses transindividuais, parte da doutrina vem admitindo uma relativização da indisponibilidade daqueles direitos ${ }^{37}$, devendo, no caso concreto, ser aplicado o princípio da proporcionalidade em todos os seus níveis, quais sejam a necessidade, a adequação e a proporcionalidade em sentido estrito ${ }^{38}$.

Para Ana Luiza $\mathrm{Nery}^{39}$, a possibilidade de que se implementem concessões recíprocas no termo de ajustamento, numa relativização da indisponibilidade dos direitos transindividuais, deriva do permissivo legal constante no artigo $5^{\circ}, \S 6^{\circ}$, da Lei da Ação

\footnotetext{
${ }^{34}$ Acerca do referido "dogma”, vide FERRAJOLI, Luigi. Los fundamentos de los derechos fundamentales. Madrid: Editorial Trotta, 2001, p. 32.

${ }^{35}$ PINHO, Humberto Dalla Bernardina de; VIDAL, Ludmilla Camacho Duarte. Primeiras reflexões sobre os impactos do novo CPC e da Lei de Mediação no compromisso de ajustamento de conduta. Revista de Processo, São Paulo, vol. 256, p. 371-409, jun. 2016.

36 Nesse sentido, ainda que se admita uma relativização da indisponibilidade do direito transindividual, deverá ser preservada a sua essência, qual seja o seu aspecto substancial, sob pena de grave afronta aos interesses da coletividade.

${ }^{37}$ Dentre vários autores que sustentam essa posição, merecem destaque MARTINS, Pedro Antônio Batista; LEMES, Selma; CARMONA, Carlos Alberto. Aspectos fundamentais da Lei de Arbitragem. Rio de Janeiro: Forense, 1999, p. 319; PEREIRA, Marco Antonio Marcondes. Transação no curso da ação civil pública. Revista de Direito do Consumidor, São Paulo, vol. 16, out./dez. 1995, p. 125; e MORAES, Paulo Valério Dal Pai. O compromisso de ajustamento. Revista de Processo, São Paulo, vol. 30, p. 28-48, abr./jun. 1999.

${ }^{38}$ Como verdadeira técnica de ponderação, já usualmente empregada pela administração pública e pelo Poder Judiciário.

${ }^{39}$ NERY, Ana Luiza. Teoria geral do termo de ajustamento de conduta. São Paulo: Revista dos Tribunais, 2017, e-book.
} 
Revista Eletrônica de Direito Processual - REDP.

Rio de Janeiro. Ano 16. Volume 23. Número 1. Janeiro a Abril de 2022

Periódico Quadrimestral da Pós-Graduação Stricto Sensu em Direito Processual da UERJ

Patrono: José Carlos Barbosa Moreira (in mem.). ISSN 1982-7636. pp. 1113-1141

www.redp.uerj.br

Civil Pública, bem como a partir da legitimidade concorrente e disjuntiva dos órgãos insertos no caput do apontado dispositivo legal, visto que foi conferida margem de liberalidade a esses colegitimados, inclusive com autorização expressa da negociação do compromisso, conferindo-lhes capacidade para celebrar a transação negociada.

A partir dessa concepção, desde que não haja renúncia ao direito coletivo em sua essência - qual seja o seu núcleo substancial, nada impede que ocorram concessões acerca de questões secundárias ou acessórias que circundam aquele direito ou interesse transindividual.

Isso se coaduna com a ideia de que a negociação da melhor solução possível, no âmbito da tutela coletiva, por intermédio do termo de ajustamento, é o caminho mais rápido e eficiente a destoar de uma judicialização morosa e inábil. Com a consolidação de um resultado benéfico para a coletividade e para o interessado que se obriga, dá-se uma verdadeira solução concertada ao conflito coletivo de interesses.

Desta feita, com amparo numa doutrina moderna e coadunada com a necessidade de solucionar conflitos coletivos cada vez mais complexos, a qual se opõe à noção clássica de indisponibilidade irrestrita dos direitos transindividuais, é possível defender a relativa disponibilidade de tais direitos e interesses.

No entanto, a resguardar minimamente os direitos e interesses coletivos lato sensu, os autores Humberto Dalla Bernardina de Pinho e Bianca Oliveira de Farias ${ }^{40}$ defendem a aplicação de alguns limites a serem observados durante a celebração do TAC.

Nesse sentido, sem prejuízo da adoção do princípio da proporcionalidade no caso concreto, o compromisso de ajustamento não pode fixar cláusulas que impeçam o acesso dos lesados ao Poder Judiciário, sob pena de flagrante violação ao princípio do amplo acesso à justiça, assim previsto no artigo $5^{\circ}$, inciso XXXV, da Constituição Federal.

Outrossim, para os referidos autores, não pode o termo de ajuste incluir renúncias ao núcleo substancial do direito material, conforme acima já apontado, o que não impediria a renúncia a uma obrigação acessória ou de uma parte inexpressiva da obrigação principal.

De tal arte, resguardada a essência do direito material, toda e qualquer outra obrigação pode ser objeto de negociação entre os signatários do ajustamento de conduta,

40 PINHO, Humberto Dalla Bernardina de; FARIAS, Bianca Oliveira de. Apontamentos sobre o compromisso de ajustamento de conduta na Lei de Improbidade Administrativa e no Projeto de Lei da Ação Civil Pública. Revista Eletrônica de Direito Processual, Rio de Janeiro, vol. IV, p. 25-53, 2009. 
Revista Eletrônica de Direito Processual - REDP.

Rio de Janeiro. Ano 16. Volume 23. Número 1. Janeiro a Abril de 2022

Periódico Quadrimestral da Pós-Graduação Stricto Sensu em Direito Processual da UERJ

Patrono: José Carlos Barbosa Moreira (in mem.). ISSN 1982-7636. pp. 1113-1141

www.redp.uerj.br

que, para ser eficaz, deve repercutir positivamente tanto para a administração pública ou coletividade, quanto para o interessado, seja este uma pessoa física ou jurídica, de direito público ou privado.

Tal posicionamento, apesar de controverso na doutrina, assegura aos órgãos colegitimados para a celebração do termo de ajuste uma autonomia ampla na autocomposição dos conflitos que versem acerca de direitos ou interesses metaindividuais, tudo em consonância com uma implementação de políticas públicas e/ou efetivação de direitos fundamentais mais eficiente.

\section{EXISTENCIA E VALIDADE DO TERMO DE AJUSTAMENTO DE CONDUTA}

Uma vez admitido que o termo de ajustamento é um negócio jurídico, a sua existência depende da presença de seus elementos constitutivos ${ }^{41}$, quais sejam ao menos dois sujeitos de direito, que manifestem suas vontades, visando um fim determinado. Portanto, são elementos de existência: agentes, vontades, e causa.

Com a ausência de um dos elementos acima destacados, o termo de ajuste inexiste, não produzindo, por óbvio, qualquer efeito. Para que exista, como ocorre com todo negócio jurídico, o compromisso de ajustamento deve prever, além dos seus elementos acima indicados -, inúmeros requisitos formais ${ }^{42}$, que podem ser assim entabulados:

a) forma escrita, devendo ser reduzido a termo;

b) objeto determinando as obrigações de fazer e/ou de não fazer, com a estipulação de sua forma de cumprimento;

c) se acaso houver obrigação de pagar quantia certa ou de entregar coisa, em sede de obrigação de indenizar, deverá haver expressa previsão;

d) cominação de multa a incidir na hipótese de descumprimento das obrigações pactuadas;

e) indicação do destino do valor arrecadado, seja em sede de obrigação de

\footnotetext{
${ }^{41}$ NERY, Ana Luiza. Teoria geral do termo de ajustamento de conduta. São Paulo: Revista dos Tribunais, 2017, e-book.

42 Tais requisitos são extraídos, em síntese, da Resolução n. 179, de 26 de julho de 2017, do Conselho Nacional do Ministério Público, que regulamenta o $\S 6^{\circ}$ do artigo $5^{\circ}$ da Lei n. $7.347 / 85$, disciplinando, no âmbito do Ministério Público, a tomada do compromisso de ajustamento de conduta, a qual pode ser aplicada por analogia quando o termo restar celebrado por outro colegitimado.
} 
indenizar, seja por força de multa cominatória na hipótese de inadimplemento das obrigações assumidas;

f) data e assinatura dos pactuantes;

g) lugar de celebração;

h) tempo de vigência das cláusulas, salvo se indeterminado, e

i) liquidez e certeza do título executivo extrajudicial.

Acerca dos apontados requisitos formais, um aspecto que merece uma análise mais detida está relacionado com as cominações passíveis de previsão no ajustamento, que compreendem as sanções civis previstas no termo para a hipótese de inadimplemento, ainda que parcial ${ }^{43}$.

Em regra, tais cominações, de caráter pecuniário, possuem natureza de cláusula penal, sendo convencionada pelos signatários, a qual incide na hipótese de mora ou para assegurar outra cláusula determinada, admitindo-se ao órgão público legitimado exigir tanto a satisfação da obrigação principal, como também o pagamento da multa na eventualidade do descumprimento daquela ${ }^{44}$.

No entanto, além do plano da existência do negócio jurídico, há, ainda, a perspectiva de sua validade, que $e^{45}$, essencialmente, a qualidade que deve possuir ao adentrar no mundo jurídico, sendo indicativo de regularidade e de consonância com as regras jurídicas.

Nesse sentido, para que o termo de ajustamento de conduta seja reputado válido, devem haver seus requisitos de validade, quais sejam ao menos dois agentes capazes - o colegitimado e o(s) interessado(s); a manifestação de vontade, desprovida de qualquer vício; a licitude e possibilidade do objeto; e a forma escrita ${ }^{46}$.

\footnotetext{
${ }^{43}$ Acerca desse tema, vide VIEIRA, Fernando Grella. A transação nos interesses difusos e coletivos. In: MILARÉ, Edis (coord.). Ação civil pública: Lei 7.347/1985: 15 anos. 2. ed. São Paulo: Revista dos Tribunais, 2002.

${ }^{44}$ Para aprofundar acerca do assunto, vide Ana Luiza Nery, na obra já referida anteriormente, que sustenta, no entanto, diferentemente do acima apontado, um ônus exagerado atribuir ao interessado, no termo de ajustamento de conduta, a obrigatoriedade do pagamento da multa em caso de inadimplemento, bem como da obrigação principal.

${ }^{45}$ AZEVEDO, Antonio Junqueira de. Negócio jurídico: existência, validade e eficácia. 4. ed. São Paulo: Saraiva, 2002, p. 42.

${ }^{46}$ Ao admitir a natureza de negócio jurídico ao termo de ajustamento de conduta, extrai-se do artigo 104 do Código Civil, os seus requisitos de validade. Nesse sentido: "Art. 104: A validade do negócio jurídico requer: I - agente capaz; II - objeto lícito, possivel, determinado ou determinável; III - forma prescrita ou não defesa em lei."
} 
Revista Eletrônica de Direito Processual - REDP.

Rio de Janeiro. Ano 16. Volume 23. Número 1. Janeiro a Abril de 2022

Periódico Quadrimestral da Pós-Graduação Stricto Sensu em Direito Processual da UERJ

Patrono: José Carlos Barbosa Moreira (in mem.). ISSN 1982-7636. pp. 1113-1141

www.redp.uerj.br

Na tutela coletiva, tratando-se de direitos transindividuais, a legislação vigente confere legitimidade àqueles elencados no artigo $5^{\circ}$, caput, da Lei da Ação Civil Pública, para defender, em nome próprio, direito alheio, numa legitimidade concorrente e disjuntiva, o que deve ser observado no campo da validade do ajuste.

Acerca do objeto, na compreensão de que o termo em comento é uma transação bilateral, o mesmo, além de lícito, possível, determinado ou determinável, deve caracterizar, também, obrigações líquidas e certas, assegurada, ainda, a melhor solução possível para a coletividade.

Uma vez existente e válido, o termo de ajustamento de conduta mostra-se apto a ser celebrado para a solução e prevenção dos conflitos coletivos.

\section{NEGÓCIOS JURÍDICOS PROCESSUAIS E O TERMO DE AJUSTAMENTO DE CONDUTA}

Na sua essência, o termo de ajuste trata de uma solução consensual a um conflito de interesses, compondo, assim, uma convenção sobre o direito material correspondente ao acerto da questão substancial em litígio. Portanto, em regra, o ajustamento de conduta constitui um negócio jurídico que versa sobre convenções de natureza material.

No entanto, a partir da renovação implementada pelo artigo 190 do Código de Processo Civil, houve uma superação do debate preexistente acerca da ocorrência ou não dos negócios jurídicos processuais, com a previsão expressa de uma cláusula geral de negociação sobre questões processuais.

A legislação processual vigente no país, portanto, oportunizou significativo destaque às convenções processuais, seja com a previsão das hipóteses típicas ${ }^{47}$, seja com a inserção de uma cláusula geral atípica ${ }^{48}$, na qual estão previstos requisitos de validade a serem observados pelos seus subscritores.

Tal inovação normativa, para Delosmar Domingos de Mendonça Neto e Luciano

\footnotetext{
${ }^{47}$ São alguns exemplos de negócios processuais típicos, os seguintes, quais sejam a eleição negocial do foro (art. 63, CPC); o calendário processual (art. 191, $\S \S 1^{\circ}$ e $2^{\circ}, \mathrm{CPC}$ ); o acordo para suspensão do processo (art. 313, II, CPC); a convenção sobre o ônus da prova (art. 373, §§ $3^{\circ}$ e $4^{\circ}$ ); a desistência do recurso (art. 999, CPC), dentre outros.

${ }^{48}$ Qual seja o já mencionado artigo 190 do Código de Processo Civil vigente.
} 
Revista Eletrônica de Direito Processual - REDP.

Rio de Janeiro. Ano 16. Volume 23. Número 1. Janeiro a Abril de 2022

Periódico Quadrimestral da Pós-Graduação Stricto Sensu em Direito Processual da UERJ

Patrono: José Carlos Barbosa Moreira (in mem.). ISSN 1982-7636. pp. 1113-1141

www.redp.uerj.br

Cezar Vernalha Guimarães ${ }^{49}$, oportunizou que os interessados estabeleçam o rito processual, ou parte dele, da maneira que melhor lhes aprouver, com a ampliação do espaço de acordo sobre aspectos processuais, numa verdadeira flexibilização do processo.

Para os referidos autores ${ }^{50}$, inclusive, a cláusula geral prevista no artigo 190 do Diploma Processual Civil pátrio apresenta elementos que caracterizam os negócios jurídicos processuais, quais sejam: a) versar sobre direitos que admitam autocomposição; b) a eventual mudança no procedimento deve ocorrer para ajustá-lo às questões específicas do caso concreto; c) versar acerca de ônus, poderes, faculdades e deveres processuais; e d) ser celebrados durante ou antes do processo.

Desta feita, compreendendo o negócio processual, segundo Fredie Didier Jr. ${ }^{51}$, como "o fato jurídico voluntário, em cujo suporte fático se confere ao sujeito o poder de regular, dentro dos limites fixados no próprio ordenamento jurídico, certas situações jurídicas processuais", não há dúvida de que convenções processuais podem ser inseridas como cláusulas de um termo de ajustamento.

Inclusive, a Resolução n. 118, de $1^{\circ}$ de dezembro de 2014, do Conselho Nacional do Ministério Público, em seu artigo 17, prevê expressamente a possibilidade de que o compromisso de ajustamento traga, no seu conteúdo, convenções processuais "celebradas de maneira dialogal e colaborativa, com o objetivo de restaurar o convívio social e a efetiva pacificação dos relacionamentos por intermédio da harmonização entre os envolvidos".

Assim sendo, desde que observados os limites versados no artigo 190 do Código de Processo Civil ${ }^{52}$, poderão os subscritores do termo de ajustamento celebrar negócios processuais nas suas cláusulas. Nesse sentido, conforme já explicitado num tópico

\footnotetext{
${ }^{49}$ MENDONÇA NETO, Delosmar Domingos de; GUIMARÃES, Luciano Cezar Vernalha. Negócio jurídico processual, direitos que admitem a autocomposição e o pactum de non petendo. Revista de Processo, São Paulo, vol. 272, out. 2017, p. 420.

${ }^{50}$ MENDONÇA NETO, Delosmar Domingos de; GUIMARÃES, Luciano Cezar Vernalha. Negócio jurídico processual, direitos que admitem a autocomposição e o pactum de non petendo. Revista de Processo, São Paulo, vol. 272, out. 2017, p. 422.

${ }^{51}$ DIDIER JR., Fredie. Ensaios sobre os negócios jurídicos processuais. Salvador: Editora Juspodvm, 2018, p. 25.

${ }^{52}$ Não se desconhece que, como qualquer negócio jurídico, os negócios processuais devem ser observados a partir do plano de validade dos atos jurídicos, e não apenas quanto aos limites descritos no artigo 190 do Código de Processo Civil, o que, no entanto, não será tratado no presente trabalho, sob risco de fuga do tema principal a ser estudado.
} 
Revista Eletrônica de Direito Processual - REDP.

Rio de Janeiro. Ano 16. Volume 23. Número 1. Janeiro a Abril de 2022

Periódico Quadrimestral da Pós-Graduação Stricto Sensu em Direito Processual da UERJ

Patrono: José Carlos Barbosa Moreira (in mem.). ISSN 1982-7636. pp. 1113-1141

www.redp.uerj.br

anterior $^{53}$, ainda que indisponíveis os interesses e direitos existentes no âmbito da tutela coletiva, nada impede que haja a celebração de negócio processual no termo de ajuste ${ }^{54}$, desde que resguardado o núcleo essencial daqueles e observada a vedação de suas renúncias por completo.

Além disso, a convenção processual pode ser celebrada antes do ajuizamento da ação coletiva, sendo, assim, muito útil na solução concertada de conflitos coletivos, com a inserção de cláusulas negociadas de cunho processual para a eventualidade do ajuizamento da demanda. Há, portanto, nessa hipótese, através do termo de ajustamento, um negócio jurídico processual precedente, a repercutir num eventual processo futuro que esteja relacionado com aquela negociação.

Admitida, ainda, pela doutrina, a celebração do termo de ajuste durante uma ação coletiva, nada impede, também, que haja a inserção de cláusulas processuais no seu interior, pois o negócio jurídico pode alcançar, por expressa previsão do artigo 190 do Código de 2015 vigente, o processo atual.

Com essas observações, o termo de ajustamento, que traga consigo um negócio processual, deverá receber rigoroso controle jurisdicional no curso do processo, atual ou futuro, alcançado pela convenção, podendo, assim, o juiz recusar a sua aplicação no caso de ser nula, bem como na eventualidade de ser inserida de forma abusiva em um contrato de adesão ou, ainda, quando apresentar uma situação de manifesta abusividade, conforme a disposição contida no parágrafo único, do artigo 190 do Código de 2015.

Uma questão polêmica, envolvendo os negócios processuais e o termo de ajustamento de conduta, diz respeito à possibilidade de inserção do pactum de non petendo no seu interior, qual seja o acordo através do qual os interessados celebram a impossibilidade de exigir, judicialmente, uma dada obrigação. No apontado pacto, há um acordo versando acerca do direito da parte credora a exigir judicialmente do outro o cumprimento da obrigação ${ }^{55}$.

\footnotetext{
${ }^{53}$ Esse tema foi analisado no tópico 1.3 do texto em tela, onde foram apresentadas as controvérsias quanto a possibilidade de transação, no termo de ajustamento de conduta, quanto aos direitos ditos indisponíveis.

54 Nesse sentido, vide MENDONÇA NETO, Delosmar Domingos de; GUIMARÃES, Luciano Cezar Vernalha. Negócio jurídico processual, direitos que admitem a autocomposição e o pactum de non petendo. Revista de Processo, São Paulo, vol. 272, p. 419-439, out. 2017.

${ }^{55}$ Para COSTA E SILVA, Paula. Pactum de non petendo: exclusão convencionado do direito de acção e exclusão convencional da pretensão material. In: CABRAL, Antonio do Passo; NOGUEIRA, Pedro Henrique (coords.). Negócios processuais. Salvador: Editora Juspodvm, 2015, p. 305, não há qualquer
} 
Revista Eletrônica de Direito Processual - REDP.

Rio de Janeiro. Ano 16. Volume 23. Número 1. Janeiro a Abril de 2022

Periódico Quadrimestral da Pós-Graduação Stricto Sensu em Direito Processual da UERJ

Patrono: José Carlos Barbosa Moreira (in mem.). ISSN 1982-7636. pp. 1113-1141

www.redp.uerj.br

Ainda que haja autores sustentando a inconstitucionalidade do pactum de non petendo, por supostamente violar o direito de ação, bem como o princípio constitucional da inafastabilidade de jurisdição, para José Manoel de Arruda Alvim Netto ${ }^{56}$, a parte, “dentro do âmbito de sua esfera e no exercício legítimo de sua autonomia privada, pode legitimamente assim pactuar".

No entanto, apesar de admitida a celebração de negócios processuais no interior de um termo de ajuste, e ainda que se compreenda, em caráter geral, como constitucional o pactum de non petendo, quando o conflito de interesses versar acerca de direitos difusos, coletivos ou individuais indisponíveis, nos quais não se admite a sua renúncia, ter-se-á como incabível o referido pacto na hipótese de inadimplemento da obrigação avençada.

Se por um lado, havendo o adimplemento da obrigação assumida no termo de ajustamento de conduta, e consequente solução efetiva do conflito coletivo, não persiste qualquer interesse processual para ajuizar a demanda, mostrando-se desnecessário o pactum de non petendo; por outro lado, não se mostra razoável e proporcional, nem mesmo constitucional, a inclusão do apontado pacto, numa das cláusulas do ajuste, a incidir numa eventual inadimplência da obrigação indisponível assumida pelo interessado.

Nesse sentido, não se mostra razoável e proporcional, ante a natureza indisponível, ainda que relativa, dos direitos coletivos lato sensu tutelados no âmbito do termo de ajustamento de conduta, visto que acarretaria numa renúncia do seu núcleo essencial, o que é vedado pelo ordenamento jurídico pátrio.

E também não se apresenta constitucional, nesta hipótese específica, por excluir da apreciação jurisdicional um conflito que versa acerca de direitos de titularidade transindividual, cuja tutela não se mostrou satisfatória na via consensual ${ }^{57}$, a exigir, portanto, o amplo acesso ao Poder Judiciário com a inafastabilidade da jurisdição, numa interpretação consentânea com o disposto no artigo $5^{\circ}$, inciso XXXV, da Constituição Federal e no artigo 190 do Código de Processo Civil vigente ${ }^{58}$.

dúvida de que o apontado negócio processual não incide sobre o próprio direito de crédito, mas, na verdade, ao direito de exigir judicialmente o seu cumprimento.

${ }^{56}$ ALVIM NETTO, José Manoel de Arruda. Soluções práticas de direito: pareceres. Direito Privado I. São Paulo: Editora Revista dos Tribunais, 2011, v. II, p. 987.

57 Apesar da tentativa de autocomposição através do termo de ajustamento de conduta, não houve, no caso hipotético em tela, um resultado frutífero, devendo a demanda ser objeto de judicialização a reparar ou prevenir uma lesão ou ameaça de lesão a um direito coletivo lato sensu.

58 Outra questão controversa, mas um tanto quanto distinta da acima analisada, e que será objeto de um 
Revista Eletrônica de Direito Processual - REDP.

Rio de Janeiro. Ano 16. Volume 23. Número 1. Janeiro a Abril de 2022

Periódico Quadrimestral da Pós-Graduação Stricto Sensu em Direito Processual da UERJ

Patrono: José Carlos Barbosa Moreira (in mem.). ISSN 1982-7636. pp. 1113-1141

www.redp.uerj.br

\section{A MEDiaÇÃo, A CONCILIAÇÃo E O TERMO DE AJUSTAMENTO DE CONDUTA}

\subsection{A mediação nos conflitos que envolvem direitos coletivos lato sensu}

Como uma das formas de autocomposição dos litígios, a mediação é marcada pela figura do mediador, que atua para neutralizar as emoções dos envolvidos numa intermediação do acordo, sem, contudo, interferir no seu conteúdo.

Não há dúvida de que a mediação, até mesmo pelo seu caráter consensual e pacificador, possui vantagens se comparada à atividade jurisdicional. A uma, por se mostrar mais rápida e econômica do que a solução judicial dos conflitos. A duas, em razão de possibilitar a construção de soluções reciprocamente favoráveis, o que, em regra, não se mostra apto no bojo de um processo. A três, ante a possibilidade de que as partes possam escolher, em comum acordo, o mediador, segundo suas qualificações pessoais, ao contrário dos critérios fixos e prévios de competência jurisdicional.

Através da Lei n. 13.140, sancionada em 26 de junho de 2015, a mediação foi disciplinada no ordenamento jurídico brasileiro com a fixação dos seus princípios orientadores $^{59}$, além da previsão do seu emprego nos conflitos que versam sobre direitos disponíveis ou naqueles direitos indisponíveis que admitam transação.

Em razão disso, as discussões outrora existentes acerca da possibilidade de emprego da mediação como meio de solução consensual dos conflitos coletivos, inclusive

trabalho futuro, diz respeito à possibilidade dos signatários, no bojo de um termo de ajustamento de conduta, convencionarem a retirada da eficácia de título executivo através de um negócio processual. Analisando genericamente a questão, assim ensinam DIDIER JR., Fredie; CABRAL, Antônio do Passo. Negócios jurídicos processuais atípicos e execução. Revista do Ministério Público do Rio de Janeiro, Rio de Janeiro, $\mathrm{n}$. 67, jan./mar. 2018, p. 147, na lição que segue transcrita: "Primeiro, poderiam as partes convencionar para retirar a eficácia de título executivo de algum documento que conste da lista do art. 784 do CPC, porque a executividade de um título é efeito que se encontra no âmbito da disponibilidade do credor, que pode, inclusive, optar por não promover a execução. As partes podem, por exemplo, decidir que o título serve apenas à ação monitória. $O$ art. 785 do CPC, que permite ao sujeito que possua título executivo propor ação de conhecimento, em vez de ação de execução, reforça esse entendimento."

${ }^{59} \mathrm{O}$ artigo $2^{\circ}$ da Lei n. 13.140/2015 enunciou os seguintes princípios orientadores da mediação, quais sejam a imparcialidade do mediador, a isonomia entre as partes, a oralidade, a informalidade, a autonomia da vontade das partes, a busca do consenso, a confidencialidade e a boa-fé. 
Revista Eletrônica de Direito Processual - REDP.

Rio de Janeiro. Ano 16. Volume 23. Número 1. Janeiro a Abril de 2022

Periódico Quadrimestral da Pós-Graduação Stricto Sensu em Direito Processual da UERJ

Patrono: José Carlos Barbosa Moreira (in mem.). ISSN 1982-7636. pp. 1113-1141

www.redp.uerj.br

daqueles que tenham como conteúdo os direitos fundamentais sociais ${ }^{60}$, perdeu significância. Ainda que se tratem de direitos coletivos lato sensu de natureza indisponível, se admitida a transação, será possível, numa interpretação literal do disposto na Lei n. 13.140/2015, a mediação.

Os conflitos coletivos, que poderão ter por objeto obrigações de fazer, de não fazer ou, até mesmo, de entregar coisas certas ou de pagar quantia, em regra alcançam questões relacionadas com serviços públicos variados, ou, ainda, estão relacionados com a prevenção ou reparação de lesões ao meio ambiente, ao patrimônio público, aos interesses dos consumidores, dentre outros aspectos.

Por assim ser, a mediação coletiva pode ser judicial ou extrajudicial, distinguindose quanto ao momento de sua utilização, se antes do processo ou no curso do mesmo.

$\mathrm{Na}$ mediação judicial, o mediador poderá ser escolhido pelas partes, de comum acordo, ou, inexistindo acordo quanto à escolha, haverá distribuição do processo entre aqueles cadastrados no registro do tribunal, o que se apresenta descrito no artigo 168 do Código de Processo Civil vigente ${ }^{61}$.

Nessa hipótese, a mediação deve ser instaurada, incidentalmente, no âmbito do processo coletivo, quando, então, será designada uma sessão de mediação. Se a demanda versar sobre direitos fundamentais sociais, e a ação coletiva não tiver sido ajuizada pelo Ministério Público, a sua intervenção será obrigatória, sob pena de nulidade insanável, sendo essa a interpretação que se extrai do disposto no artigo 178 do Diploma Processual Civil.

Concluído o acordo, no bojo do processo coletivo, o seu conteúdo deve ser submetido à homologação judicial, circunstância em que o juízo deverá verificar a validade e licitude dos seus termos, bem como a existência de sanções para o caso de descumprimento das obrigações acordadas, até mesmo para estimular o seu adimplemento.

Já no que se refere à mediação extrajudicial, incumbindo aos interessados a eleição do mediador, a Lei de Mediação prevê a elaboração de um contrato prévio, denominado de

\footnotetext{
60 Nesse sentido, vide CAMBI, Eduardo; HAAS, Adriane. Mediação de conflitos envolvendo direitos fundamentais sociais. Revista de Processo, São Paulo, vol. 289, mar. 2019, p. 477.

${ }^{61}$ Apesar do artigo 25 da Lei de Mediação preconizar que, na mediação judicial, os mediadores não estarão sujeitos à prévia aceitação da parte, a doutrina majoritária, numa interpretação sistemática, defende a escolha pelas partes. Nesse sentido, vide TARTUCE, Fernanda. Mediação nos conflitos civis. 3. ed. Rio de Janeiro: Forense; São Paulo: Método, 2016, p. 297-299.
} 
Revista Eletrônica de Direito Processual - REDP.

Rio de Janeiro. Ano 16. Volume 23. Número 1. Janeiro a Abril de 2022

Periódico Quadrimestral da Pós-Graduação Stricto Sensu em Direito Processual da UERJ

Patrono: José Carlos Barbosa Moreira (in mem.). ISSN 1982-7636. pp. 1113-1141

www.redp.uerj.br

"previsão contratual de mediação"62. Por se tratar de um modo de solução extrajudicial de conflitos, apresenta-se recomendável que ocorra anteriormente à judicialização da demanda, até mesmo para que a interlocução entre os interessados ocorra da maneira mais ampla possível, assegurando, assim, na tutela coletiva, uma maior resolutividade aos direitos e interesses ameaçados ou lesados.

Nada impede, por certo, que haja a entabulação de acordo por intermédio da mediação, num conflito coletivo, no curso do inquérito civil público, ou, ainda, de um procedimento administrativo diverso deste último, o que culminará num título executivo extrajudicial ${ }^{63}$.

\subsection{A conciliação nos conflitos que envolvem direitos coletivos lato sensu}

Caminhando paralelamente à mediação, como instrumento também essencial para a prevenção ou solução de conflitos de interesses coletivos, a conciliação foi destacada no Código de Processo Civil vigente, que está estruturado sob o princípio do estímulo da solução por autocomposição ${ }^{64}$.

No entanto, há uma distinção inicial entre os dois mencionados modos de solução consensual de conflitos. Enquanto na conciliação, após ouvir os interessados, o conciliador sugere uma solução; na mediação, o mediador induz as partes a descobrirem a motivação do conflito para que cheguem à prevenção ou solução da controvérsia.

Para Daniel Colnago Rodrigues ${ }^{65}$, a conciliação e a mediação são distinguidas a partir de alguns critérios. Acerca da finalidade, a conciliação busca resolver o conflito conforme apresentado pelos interessados; enquanto que, na mediação, a solução dada seria mais abrangente. No que se refere ao método, para o apontado autor, a atividade do conciliador seria mais intensa do que a atuação do mediador, visto que se admite, inclusive, uma sugestão dos termos do acordo.

\footnotetext{
${ }^{62}$ Conforme previsto no artigo 22, e seguintes, da Lei n. 13.140/2015.

${ }^{63}$ Conforme previsto no artigo 20, parágrafo único, da já apontada Lei n. 13.140/2015, sendo, ao término da mediação, lavrado um termo final, que constitui o título executivo extrajudicial.

${ }^{64}$ Nesse sentido, DIDIER JR., Fredie. Curso de direito processual civil: introdução ao direito processual civil, parte geral e processo de conhecimento. 21 ed. Salvador: Editora Juspodvm, 2019, p. 274.

65 RODRIGUES, Daniel Colnago. Mediação obrigatória no processo civil: reflexões à luz do direito comparado, do CPC/2015 e da Lei de Mediação (Lei 13.140/2015). Revista de Processo, São Paulo, vol. 285, nov. 2018, p. 367.
} 
Revista Eletrônica de Direito Processual - REDP.

Rio de Janeiro. Ano 16. Volume 23. Número 1. Janeiro a Abril de 2022

Periódico Quadrimestral da Pós-Graduação Stricto Sensu em Direito Processual da UERJ

Patrono: José Carlos Barbosa Moreira (in mem.). ISSN 1982-7636. pp. 1113-1141

www.redp.uerj.br

Já para Erika Zanon Soares ${ }^{66}$, na conciliação, em que os interessados são auxiliados por um terceiro imparcial e neutro, objetiva-se uma rápida solução, qual seja um acordo para adimplemento, devendo ser utilizada preferencialmente quando não existir vínculo anterior entre os indivíduos em conflito ${ }^{67}$.

Por certo, a conciliação, para se mostrar frutífera, deve ser coordenada por um terceiro imparcial e qualificado para aproximar os interessados, sugerir e formular propostas, tendo, assim, a prerrogativa de construir um possível acordo, que deverá ser avaliado quanto as vantagens e desvantagens pelos envolvidos.

Ainda que a mediação e a conciliação apresentem sutis distinções e estratégias, ambas, como modos de autocomposição de conflitos, mostram-se essenciais para a efetivação dos direitos coletivos lato sensu, principalmente num contexto de crise na prestação jurisdicional e de onerosidade do processo.

Embora a conciliação não seja um instrumento novo, sempre houve a sua subutilização, o que, a partir do Código de Processo Civil vigente, da Resolução n. 125/2020 do Conselho Nacional de Justiça ${ }^{68}$ e da Resolução n. 118/2014 do Conselho Nacional do Ministério Público, deve ser imperiosamente superado.

Seja judicial, ou, ainda, pré-processual, quando desenvolvida antes da instauração de um processo, a conciliação deve ser compreendida como uma etapa indispensável antes da intervenção estatal no conflito.

Quando se tratarem de direitos transindividuais, a conciliação pode ocorrer, inclusive, no âmbito do inquérito civil público ou de outro procedimento administrativo correlato, sendo que as tratativas para a composição devem contar com a participação de um terceiro, qual seja o próprio conciliador. Ao final, com a celebração do acordo, dá-se a redução a termo para posterior homologação judicial.

Sejam direitos difusos ou coletivos, sejam direitos individuais homogêneos, a conciliação apresenta uma vocação para produzir resultados frutíferos ${ }^{69}$. Primeiramente,

\footnotetext{
${ }^{66}$ SOARES, Erika Zanon. Conciliação e o Código de Processo Civil. In: NUNES, Ana (coord.). Mediação e conciliação: teoria e prática. São Paulo: Thomson Reuters Brasil, 2018, e-book.

${ }^{67}$ Inclusive, é essa a interpretação que se extrai do disposto no artigo 165 , $\S \S 2^{\circ}$ e $3^{\circ}$, do Código de Processo Civil.

${ }^{68}$ Nesse sentido, a já mencionada autora Erika Zanon Soares, na obra acima referida.

69 Nesse diapasão, vide MERÇON-VARGAS, Sarah. Meios alternativos na resolução de conflitos de interesses transindividuais. Tese (Doutorado em Direito) - Faculdade de Direito da Universidade de São Paulo. São Paulo, 2012.
} 
Revista Eletrônica de Direito Processual - REDP.

Rio de Janeiro. Ano 16. Volume 23. Número 1. Janeiro a Abril de 2022

Periódico Quadrimestral da Pós-Graduação Stricto Sensu em Direito Processual da UERJ

Patrono: José Carlos Barbosa Moreira (in mem.). ISSN 1982-7636. pp. 1113-1141

www.redp.uerj.br

em razão dos seus custos serem insignificantes ${ }^{70}$, não exigindo, ainda, um longo decurso temporal para a sua utilização. Além disso, a presença do legitimado coletivo na conciliação acaba por neutralizar um possível desequilíbrio no litígio, se este permanecesse individualizado.

A opção entre a mediação e a conciliação deve se fundar nas circunstâncias do caso concreto, sendo, no entanto, dois instrumentos de pacificação social indispensáveis na tutela coletiva, cujo emprego deve ser o mais difundido e incentivado possível. Pensar de maneira distinta, é coadunar com uma postergação demasiada dos conflitos coletivos, sem qualquer previsão de solução, o que redunda em prejuízos, muitas vezes, insanáveis à sociedade.

\subsection{A mediação, a conciliação e o termo de ajustamento de conduta}

Visto que, através do termo de ajustamento de conduta, os signatários autorregulam seus interesses, assim destinados, em regra, a uma adequação das condutas às exigências legais, evidente que a mediação e a conciliação acabam por ser úteis para a sua celebração.

Ainda que a elaboração e a subscrição do termo de ajuste não necessitem rigorosamente da mediação e da conciliação, estas, por certo, são formas de soluções consensuais de conflitos que objetivam que as partes, ao final das conversações, alcancem uma autocomposição.

Nesse raciocínio, o termo de ajustamento de conduta e a mediação/conciliação não se tratam de institutos distintos, mas, na verdade, complementares, sendo a mediação e a conciliação técnicas essencialmente úteis para a celebração do apontado título executivo extrajudicial.

Para Ana Luiza Nery ${ }^{71}$, no âmbito da administração pública, poderão ser instituídas câmaras de mediação e conciliação, com o objetivo de avaliar a possibilidade de resolução de conflitos, promovendo, ainda, a partir de tais técnicas, a subscrição de um termo de ajustamento de conduta.

\footnotetext{
${ }^{70}$ Com a redução, ou até mesmo a eliminação, de custas e despesas judiciais, honorários de sucumbência e advocatícios, conforme o caso concreto.

${ }^{71}$ NERY, Ana Luiza. Teoria geral do termo de ajustamento de conduta. São Paulo: Revista dos Tribunais, 2017, e-book.
} 
Revista Eletrônica de Direito Processual - REDP.

Rio de Janeiro. Ano 16. Volume 23. Número 1. Janeiro a Abril de 2022

Periódico Quadrimestral da Pós-Graduação Stricto Sensu em Direito Processual da UERJ

Patrono: José Carlos Barbosa Moreira (in mem.). ISSN 1982-7636. pp. 1113-1141

www.redp.uerj.br

Na Lei de Mediação, no seu Capítulo II, há previsão expressa de sua aplicação na autocomposição de conflitos envolvendo a administração pública, a alcançar, inclusive, os litígios que versem acerca de direitos indisponíveis.

Apesar de o Ministério Público, qual seja o principal subscritor de termos de ajustamento de conduta no país, não depender, em caráter imprescindível, da mediação e da conciliação para a sua celebração, necessário destacar que a já mencionada Resolução n. 118, de $1^{\circ}$ de dezembro de 2014, do Conselho Nacional do Ministério Público ${ }^{72}$, que dispõe sobre a política nacional de incentivo à autocomposição no âmbito do Ministério Público, prevê, dentre as práticas autocompositivas, a utilização da conciliação e da mediação, quando dispõe, ainda, que os membros do Ministério Público deverão ser capacitados para desenvolver tais práticas ${ }^{73}$.

Ao compreender, portanto, que a mediação e a conciliação são técnicas de solução consensual de conflitos, que se mostram úteis nas conversações prévias à celebração do termo de ajustamento de conduta, que é o instrumento que formaliza o acordo; não há como discordar da melhor doutrina ${ }^{74}$, quando sustenta que o ordenamento jurídico pátrio admite que os interessados, ao pretender celebrar um TAC, façam uso dos meios de solução consensual de conflitos, justamente para facilitar a autocomposição.

Em razão disso, naqueles casos de elevada complexidade técnica ou, ainda, de ampla repercussão social, que redundem em conflitos que versem acerca de direitos coletivos lato sensu, torna-se recomendável a participação de um terceiro imparcial à hipótese, qual seja o conciliador ou mediador, nas tratativas prévias ao termo de ajustamento de conduta.

Com isso, o órgão legitimado para a celebração do referido instrumento poderá contar com o auxílio do conciliador ou mediador, na maior parte das vezes dotado de uma

\footnotetext{
72 A partir de uma interpretação sistemática da Resolução n. 118/2014 do Conselho Nacional do Ministério Público, inarredável a conclusão de que as técnicas da mediação e da conciliação, posto que essenciais para a pacificação social, podem e devem ser empregadas previamente à celebração do termo de ajustamento de conduta.

${ }^{73}$ Nesse sentido, ALVIM, Thereza; CUNHA, Ígor Martins da. Termo de ajustamento de conduta, mediação e conciliação: uma breve reflexão a respeito do negócio jurídico que previne ou resolve conflito que envolve direitos difusos, coletivos e individuais homogêneos. Revista de Processo, São Paulo, vol. 304, jun. 2020, p. 389.

${ }^{74}$ Sustentando tal posicionamento, além dos autores referidos na nota anterior, quais sejam Thereza Alvim e Ígor Martins da Cunha, há, ainda, na doutrina pátria, a jurista Ana Luiza Nery, também na obra amplamente citada no presente artigo.
} 
Revista Eletrônica de Direito Processual - REDP.

Rio de Janeiro. Ano 16. Volume 23. Número 1. Janeiro a Abril de 2022

Periódico Quadrimestral da Pós-Graduação Stricto Sensu em Direito Processual da UERJ

Patrono: José Carlos Barbosa Moreira (in mem.). ISSN 1982-7636. pp. 1113-1141

www.redp.uerj.br

capacidade técnica indicada ao caso concreto, ou, ainda, qualificado a atuar como incentivador à autocomposição e ao estabelecimento de um ambiente favorável à solução consensual do conflito coletivo ${ }^{75}$.

Nos conflitos coletivos, geralmente marcados por questões técnicas complexas, e que versam, no mais das vezes, sobre a implementação de direitos fundamentais e/ou a efetivação de políticas públicas, o objetivo final da pacificação social torna-se mais palatável com o emprego das técnicas, amplamente debatidas acima, da mediação e da negociação, que devem ser cada vez mais aplicadas nas necessárias soluções consensuais, principalmente em tempos de crise da judicialização.

\section{CONSIDERAÇÕES FINAIS}

$\mathrm{Na}$ tutela de direitos coletivos lato sensu, a grave crise de judicialização, que se evidencia com a morosidade observada na tramitação dos processos coletivos, impõe, como necessária, a busca por meios alternativos para a pacificação social.

Em razão disso, o termo de ajustamento de conduta permanece, ainda que haja variadas questões controvertidas a seu respeito, como um importante instrumento de solução consensual dos conflitos coletivos, o qual possui um forte caráter democrático.

Compreendido como um título executivo extrajudicial, que constitui um negócio jurídico bilateral, visto que marcado por um ajuste inter partes, proveniente de uma transação, o termo de ajuste merece ser o mais difundido possível para solucionar os conflitos de interesses que tratem da efetivação dos direitos fundamentais de repercussão social, bem como da implementação de políticas públicas.

Assim, desde que resguardada a essência do direito material, até mesmo para que possa ser utilizado como um instrumento frutífero para a autocomposição, compreende-se que toda e qualquer obrigação pode ser objeto de negociação entre os signatários do ajuste de compromisso, com a adoção da ideia da relativa indisponibilidade dos direitos e interesses coletivos, a compor seja uma convenção sobre direito material, seja, ainda, um

\footnotetext{
75 Pensar dessa maneira não fragiliza a independência dos órgãos legitimados à celebração do termo de ajustamento de conduta, o que, ao contrário, se fortalece, inclusive com o apoio de um terceiro imparcial e equidistante com relação ao conflito, e com a criação da possibilidade de um maior êxito nas tratativas com os compromissários.
} 
Revista Eletrônica de Direito Processual - REDP.

Rio de Janeiro. Ano 16. Volume 23. Número 1. Janeiro a Abril de 2022

Periódico Quadrimestral da Pós-Graduação Stricto Sensu em Direito Processual da UERJ

Patrono: José Carlos Barbosa Moreira (in mem.). ISSN 1982-7636. pp. 1113-1141

www.redp.uerj.br

negócio jurídico processual.

E considerando que, através do compromisso de conduta, os seus signatários autorregulam seus interesses, evidente que a mediação e a conciliação, quais sejam duas das formas mais eficientes de solução consensual de conflitos, acabam por ser úteis para a sua celebração.

Em razão disso, e em consonância com o ordenamento jurídico pátrio, os órgãos colegitimados para a subscrição do termo de ajustamento de conduta, dentre esses o Ministério Público brasileiro, possuem, à sua disposição, as técnicas da mediação e da conciliação para a busca da melhor solução possível ao conflito que verse acerca de interesses da sociedade.

Para tanto, mostra-se essencial que tanto o Poder Judiciário, quanto o Ministério Público, em consonância com a Resolução n. 125, de 29 de novembro de 2010, do Conselho Nacional de Justiça, e com a Resolução n. 118, de $1^{\circ}$ de dezembro de 2014, do

Conselho Nacional do Ministério Público, realizem investimentos, qualificações e implementações concretas visando a ampla utilização da mediação e da conciliação na busca de soluções consensuais aos conflitos coletivos.

Em consequência, ao invés de judicializações incertas, morosas e ineptas, ter-se-á a possibilidade concreta de uma melhor e eficaz implementação de direitos fundamentais e/ou efetivação de políticas públicas, com uma rápida resposta às demandas sociais, máxima em tempos de crise, como os atuais.

\section{REFERÊNCIAS:}

ALVIM, Thereza; CUNHA, Ígor Martins da. Termo de ajustamento de conduta, mediação e conciliação: uma breve reflexão a respeito do negócio jurídico que previne ou resolve conflito que envolve direitos difusos, coletivos e individuais homogêneos. Revista de Processo, São Paulo, vol. 304, p. 379-404, jun. 2020.

ALVIM NETTO, José Manoel de Arruda. Soluções práticas de direito: pareceres. Direito Privado I. São Paulo: Editora Revista dos Tribunais, 2011, v. II.

AKAOUI, Fernando Reverendo Vidal. Compromisso de ajustamento de conduta ambiental. São Paulo: Editora Revista dos Tribunais, 2015, e-book.

AZEVEDO, Antonio Junqueira de. Negócio jurídico: existência, validade e eficácia. 4. ed. 
Revista Eletrônica de Direito Processual - REDP.

Rio de Janeiro. Ano 16. Volume 23. Número 1. Janeiro a Abril de 2022

Periódico Quadrimestral da Pós-Graduação Stricto Sensu em Direito Processual da UERJ

Patrono: José Carlos Barbosa Moreira (in mem.). ISSN 1982-7636. pp. 1113-1141

www.redp.uerj.br

São Paulo: Saraiva, 2002.

CAMBI, Eduardo; HAAS, Adriane. Mediação de conflitos envolvendo direitos fundamentais sociais. Revista de Processo, São Paulo, vol. 289, p. 473-507, mar. 2019.

CARNEIRO, Paulo Cezar Pinheiro. Acesso à Justiça: juizados especiais cíveis e ação civil pública: uma nova sistematização da teoria geral do processo. Rio de Janeiro: Forense, 2007.

CARVALHO FO., José dos Santos. Ação civil pública: comentários por artigo (Lei $n^{o}$ 7.347, de 24/7/85). 8. ed. Rio de Janeiro: Lumen Juris, 2011.

COSTA E SILVA, Paula. Pactum de non petendo: exclusão convencionado do direito de acção e exclusão convencional da pretensão material. In: CABRAL, Antonio do Passo; NOGUEIRA, Pedro Henrique (coords.). Negócios processuais. Salvador: Editora Juspodvm, 2015.

DIDIER JR., Fredie. Curso de direito processual civil: introdução ao direito processual civil, parte geral e processo de conhecimento. 21 ed. Salvador: Editora Juspodvm, 2019.

- Ensaios sobre os negócios jurídicos processuais. Salvador: Editora Juspodvm, 2018.

DIDIER JR., Fredie; CABRAL, Antônio do Passo. Negócios jurídicos processuais atípicos e execução. Revista do Ministério Público do Rio de Janeiro, Rio de Janeiro, n. 67, jan./mar. 2018

DIDIER JR., Fredie; ZANETI JR., Hermes. Curso de direito processual civil: processo coletivo. 9. ed. Salvador: Editora Juspodvm, 2014.

FERNANDES, Rodrigo. Compromisso de ajustamento de conduta ambiental. Rio de Janeiro: Renovar, 2008.

FERRAJOLI, Luigi. Los fundamentos de los derechos fundamentales. Madrid: Editorial Trotta, 2001.

FINK, Daniel Roberto. Alternativa à ação civil pública ambiental (reflexões sobre as vantagens do termo de ajustamento de conduta). In: MILARÉ, Édis. Ação civil pública: Lei 7.347/85: 15 anos. São Paulo: Revista dos Tribunais, 2001.

GAVRONSKI, Alexandre Amaral. Técnicas extraprocessuais de tutela coletiva. São 
Revista Eletrônica de Direito Processual - REDP.

Rio de Janeiro. Ano 16. Volume 23. Número 1. Janeiro a Abril de 2022

Periódico Quadrimestral da Pós-Graduação Stricto Sensu em Direito Processual da UERJ

Patrono: José Carlos Barbosa Moreira (in mem.). ISSN 1982-7636. pp. 1113-1141

www.redp.uerj.br

Paulo: Editora Revista dos Tribunais, 2010.

GRINOVER, Ada Pellegrini. O termo de ajustamento de conduta no âmbito da defesa da concorrência. Revista do IBRAC - Direito da Concorrência, Consumo e Comércio Internacional, São Paulo, vol. 16, p. 187-197, jan. 2009.

LISBÔA, Celso Anicet. Mediação e conciliação no Código de Processo Civil. Revista de Processo, São Paulo, vol. 301, p. 423-435, mar. 2020.

MACHADO, Paulo Affonso Leme. Direito ambiental brasileiro. 24 ed. São Paulo: Malheiros, 2016.

MANCUSO, Rodolfo de Camargo. Ação civil pública: em defesa do meio ambiente, do patrimônio cultural e dos consumidores: Lei $n^{\circ} 7.347 / 85$ e legislação complementar. 15. ed. São Paulo: Revista dos Tribunais, 2019, e-book.

MARTINS, Pedro Antônio Batista; LEMES, Selma; CARMONA, Carlos Alberto. Aspectos fundamentais da Lei de Arbitragem. Rio de Janeiro: Forense, 1999.

MARTINS JR., Wallace Paiva. Administração pública, resolução extrajudicial de conflitos e compromisso de ajustamento de conduta. Revista de Direito Administrativo e Infraestrutura, São Paulo, vol. 8, p. 87-126, jan./mar. 2019.

MAZZILLI, Hugo Nigro. Compromisso de ajustamento de conduta: análise à luz do anteprojeto do código brasileiro de processos coletivos. In: GRINOVER, Ada Pellegrini; MENDES, Aluisio Castro; WATANABE, Kazuo (coords.). Direito processual coletivo e o anteprojeto de código brasileiro de processos coletivos. São Paulo: Revista dos Tribunais, 2007.

MEIRELLES, Hely Lopes. Direito administrativo brasileiro. 42. ed. São Paulo: Malheiros, 2016.

MENDONÇA NETO, Delosmar Domingos de; GUIMARÃES, Luciano Cezar Vernalha. Negócio jurídico processual, direitos que admitem a autocomposição e o pactum de non petendo. Revista de Processo, São Paulo, vol. 272, p. 419-439, out. 2017.

MERÇON-VARGAS, Sarah. Meios alternativos na resolução de conflitos de interesses transindividuais. Tese (Doutorado em Direito) - Faculdade de Direito da Universidade de São Paulo. São Paulo, 2012.

MORAES, Paulo Valério Dal Pai. O compromisso de ajustamento. Revista de Processo, São Paulo, vol. 30, p. 28-48, abr./jun. 1999. 
Revista Eletrônica de Direito Processual - REDP.

Rio de Janeiro. Ano 16. Volume 23. Número 1. Janeiro a Abril de 2022

Periódico Quadrimestral da Pós-Graduação Stricto Sensu em Direito Processual da UERJ

Patrono: José Carlos Barbosa Moreira (in mem.). ISSN 1982-7636. pp. 1113-1141

www.redp.uerj.br

MOREIRA, José Carlos Barbosa. A proteção jurisdicional dos interesses coletivos ou difusos. In: GRINOVER, Ada Pellegrini (coord.). A tutela dos interesses difusos. São Paulo: Max Limonad, p. 193-221, 1984.

NERY, Ana Luiza. Teoria geral do termo de ajustamento de conduta. São Paulo: Revista dos Tribunais, 2017, e-book.

NERY JR., Nelson. Código de defesa do consumidor comentado pelos autores no anteprojeto. 5. ed. Rio de Janeiro: Forense Universitária, 1998.

NUNES, Antonio Carlos Ozório. Manual de mediação: guia prático para conciliadores. São Paulo: Editora Revista dos Tribunais, 2016, e-book.

PEREIRA, Marco Antonio Marcondes. Transação no curso da ação civil pública. Revista de Direito do Consumidor, São Paulo, vol. 16, p. 116-128, out./dez. 1995.

PINHO, Humberto Dalla Bernardina de; FARIAS, Bianca Oliveira de. Apontamentos sobre o compromisso de ajustamento de conduta na Lei de Improbidade Administrativa e no Projeto de Lei da Ação Civil Pública. Revista Eletrônica de Direito Processual, Rio de Janeiro, vol. IV, p. 25-53, 2009.

PINHO, Humberto Dalla Bernardina de; VIDAL, Ludmilla Camacho Duarte. Primeiras reflexões sobre os impactos do novo CPC e da Lei de Mediação no compromisso de ajustamento de conduta. Revista de Processo, São Paulo, vol. 256, p. 371-409, jun. 2016.

PIZZOL, Patricia. Liquidação nas ações coletivas. São Paulo: Lejus, 1998.

RODRIGUES, Daniel Colnago. Mediação obrigatória no processo civil: reflexões à luz do direito comparado, do CPC/2015 e da Lei de Mediação (Lei 13.140/2015). Revista de Processo, São Paulo, vol. 285, p. 365-396, nov. 2018.

RODRIGUES, Geisa de Assis. Termo de Ajustamento de Conduta: a construção de uma solução extrajudicial de conflitos transindividuais democráticos. Tese (Doutorado em Direito) - Universidade do Estado do Rio de Janeiro, Rio de Janeiro, 2000.

SOARES, Erika Zanon. Conciliação e o Código de Processo Civil. In: NUNES, Ana (coord.). Mediação e conciliação: teoria e prática. São Paulo: Thomson Reuters Brasil, 2018, e-book.

SHIMURA, Sergio. Título executivo. São Paulo: Saraiva, 1997.

TARTUCE, Fernanda. Mediação nos conflitos civis. 3. ed. Rio de Janeiro: Forense; São 
Revista Eletrônica de Direito Processual - REDP.

Rio de Janeiro. Ano 16. Volume 23. Número 1. Janeiro a Abril de 2022

Periódico Quadrimestral da Pós-Graduação Stricto Sensu em Direito Processual da UERJ

Patrono: José Carlos Barbosa Moreira (in mem.). ISSN 1982-7636. pp. 1113-1141

www.redp.uerj.br

Paulo: Método, 2016.

VIEIRA, Fernando Grella. A transação nos interesses difusos e coletivos. In: MILARÉ, Edis (coord.). Ação civil pública: Lei 7.347/1985: 15 anos. 2. ed. São Paulo: Revista dos Tribunais, 2002. 